\title{
INTERNATIONAL BRANCH CAMPUS: STRATEGIC MAPPING
}

\author{
Egle GIRDZIJAUSKAITE ${ }^{1 *}$, Asta RADZEVIČIENE ${ }^{2}$, Artūras JAKUBAVIČIUS ${ }^{1}$ \\ ${ }^{I}$ Department of Business Technologies and Entrepreneurship, Faculty of Business Management, \\ Vilnius Gediminas Technical University, Saulètekio al. 11, LT-10223, Vilnius, Lithuania \\ ${ }^{2}$ Department of Management, Faculty of Business Management, Vilnius Gediminas Technical University, \\ Sauletekio al. 11, LT-10223, Vilnius, Lithuania
}

\section{"E-mail: egle.girdzijauskaite@vgtu.lt}

\begin{abstract}
Purpose - the purpose of the article is to develop a strategic map for international branch campus establishment and risk management frameworks.

Research methodology - the methods of interpretation and conceptualisation have been used to analyse the context of foreign market entry in higher education and develop strategic guidelines. Also, the results of previous research executed by authors on this topic have been used.

Findings - the decision support model for HEIs establishing an international branch campus has been suggested.

Research limitations - the main limitation of the study is the vast variety of IBCs due to its newness. However, the main aspects of establishing an IBC have been addressed and presented in a model.

Practical implications - the obtained results and the decision support model will contribute to the existing internationalisation practices of higher education institutions (HEIs) considering entering new foreign markets in the form of the international branch campus.
\end{abstract}

Originality/Value - the proposed decision support model is an instructional map for the top management in HEIs, contributing to the strategic and systematic approach to the international branch campus establishment.

Keywords: international branch campus, foreign market entry, internationalisation, HEIs, risk.

JEL Classification: I23, F23.

Conference topic: Contemporary Organizations Development Management.

\section{Introduction}

The competition in the higher education area is growing and universities are becoming more and more entrepreneurial. It is argued in the literature that universities will be run like multinational corporations and will have to incorporate business models in order to operate successfully. It is also argued that entering international markets is a source of competitiveness for universities. Thus, in the context of rising competition in international higher education, there is a pressing need for new instruments of using the business models in a foreign market entry in higher education.

The most radical foreign market mode in higher education is an international branch campus (IBC). However, there is a lack of knowledge, necessary for the strategic and systematic approach to international branch campus since it is still a relatively new phenomenon. There is a lack of algorithms on the macro environment indicators conditioning the successful international branch campus development.

In order to be able to use an IBC as a tool to enhance university competitiveness, a comprehensive decision support model for the establishment of international branch campuses focusing on university competitiveness has been developed and discussed in this paper.

In order to achieve the purpose of this paper, the following objectives were formulated: evaluate the regularities of higher education management and internationalisation, priority being given to transnational activities and IBCs; summarise the main business internationalisation theories and identify their applicability in higher education; identify and analyse international branch campus as a foreign market entry mode in higher education; develop the decision support model for international branch campus establishment modelling the development processes of a HEI.

A critical review of literature along with the methods of interpretation and conceptualization has been used to analyse the context of foreign market entry in higher education and develop strategic guidelines. Also, the results of 
previous research executed by authors on this topic (Girdzijauskaite \& Radzeviciene, 2014; Girdzijauskaite, Radzeviciene, \& Jakubavicius, 2018; Radzeviciene \& Girdzijauskaite, 2012) have been used as an empirical basis for the decision support model formation.

\section{Business internationalisation theories applied in higher education management}

Increasingly, universities are being compared to business firms in HE literature (Kim \& Zhu, 2010; Ennew, 2012; Naidoo, 2009).

In order to analyse the scope of business internationalization theories application to higher education management, five business internationalisation approaches and their applicability to higher education management are being analysed: Uppsala internationalisation theory, Eclectic paradigm, Transaction cost analysis, Industrial network approach and the Resource-based view. Theories related to the approaches, major themes and factors have been distinguished and summarised at the end of this chapter.

\subsection{Uppsala internationalization approach}

Classic research of the internationalisation of business suggests an evolutionary and sequential market commitment (Andersson et al., 1977; Johanson \& Vahlne, 1977; Buckley, Newbould, \& Thurwell, 1978). This step by step incremental approach to internationalization is usually referred to as the "Uppsala model of internationalization". It's one of the most discussed theories of the Nordic school, that has been widely supported by the researchers around the world ever since its creation. The Uppsala internationalization model suggests four steps of entering a foreign market: exporting, licensing production, joint ventures and sole ventures.

According to the Uppsala model, business companies usually start their international expansion in a market that is rather nearby in terms of psychic distance (cultural distance, differences in language, politics). After having the knowledge of the market enhanced and more international experience gathered it is time to expand to the more distance market. The Uppsala model also argues, that companies start their international operations with traditional indirect exports and gradually intensify the activities by using more demanding operation modes. All in all, concluding the Uppsala approach from a business perspective, it is known for it's an incremental approach to resource commitment and risk.

In the context of higher education internationalisation, similar frameworks seem to apply, as usually less risky modes are chosen before more aggressive ones in higher education internationalisation. For instance, following the latter logic in, traditional international student exchange between the countries could be the first step, before intensifying the activities in this market in more intensive forms (staff exchange, programme mobility, branch campus). Talking about branch campuses, a joint venture could be a step before a fully independent branch campus following this framework of intensifying export activities gradually. University of Reading in Malaysia, for example, found it effective to adopt a two-step approach when entering a new foreign market: firstly, setting up in partnership with a local institution that knows the local market, regulations, and business practices, and then later establishing an international branch campus independently (Wilkins, 2016).

However, if a joint venture is established with another HEI, the chances of turning a jointly owned IBC into an independent one are not that high, since such agreement between HEIs is very likely to be long term. University-business partnerships, on the other hand, are less likely to be long term, and therefore might be a choice to consider if aiming for a fully owned IBC in the future (Girdzijauskaite \& Radzeviciene, 2014)

It is discussed in the literature, that HEIs following this step by step Uppsala model is cautious and very controlling of their risks in the internationalization process. However, the more entrepreneurial universities with more extensive international experience might jump the stages and try riskier moves of international expansion (R. Edwards \& J. Edwards, 2001). HEIs from UK, Australia, and the USA is a good example of not necessarily following a linear internationalisation path. And those are the countries with the biggest numbers of higher education export.

As a matter of fact, the authors of the Uppsala model received a considerable amount of criticism and the model has been developed further a few times (Johanson \& Vahlne, 2009, 2017). After all, the Uppsala model was initially developed to describe the internationalisation of manufacturing companies. Therefore, it is not surprising the internationalisation of service providers like universities might follow a somewhat different path (R. Edwards \& J. Edwards, 2001).

\subsection{Eclectic paradigm}

A more comprehensive structure designed to identify all the preconditions necessary to justify the establishment of foreign production were put forward by a British economist John Dunning (1980). The theory is referred to the eclectic paradigm or the OLI-Model. The author argues that institutions must possess certain advantages in order to compete successfully overseas against the local and other international firms despite disadvantages such as language and cultural barriers.

Three important factors were distinguished in this theory (Twomey, 2000):

- Ownership advantages (trademark, production technology, entrepreneurial skills);

- Locational advantages (existence of raw materials, low wages, location-specific taxes or tariffs); 
- Internalisation advantages (advantages by producing through a partnership arrangement such as licensing or a joint venture).

All in all, eclectic paradigm is a multi-theoretical approach, including the elements of International trade theory, resource-based view theory and transaction cost theory. The key factors considered with this approach are cost, size, experiential knowledge, organizational capabilities, know-how, risk, culture, competition, market characteristics, and networks.

In a higher education setting, ownership advantages may be much less tangible and perhaps less secure than in business. The advantages that support the university at home may not apply overseas. The reputation of the university may be strongly impacted by its research output, however, if the majority of widely known leaders are only available in a home campus, and the foreign campus is staffed with junior and/or local staff who have little involvement in research, the ownership advantage doesn't transfer in this case (R. Edwards \& J. Edwards, 2001)

\subsection{Transaction cost analysis (TCA) approach}

TCA is the most popular theoretical perspective in the research on the international entry mode choice (Brouthers \& Hennart, 2007). According to TCA approach, companies choose a certain MEM in order to minimize controlling and monitoring costs (Laufs \& Schwens, 2014). The TCA approach is based on the transaction cost theory and follows a cost-efficient rationale. It deals with the costs of outsourcing the production of products or services such as transaction costs, contracting costs, coordination costs, and search costs.

In the case of higher education internationalisation, let's take an international branch campus for an example, were a university establishes a branch in order to reach the students (service buyers) in their countries. Such venture requires renting or acquiring property, hiring local academic staff and flying in academic staff from home campus, maintaining the administrative body of the branch, not to mention other operational costs. All in all, the international branch campus is undoubtedly not only expensive but also very risky. In the interviews executed by the authors in 2016 with the heads of IBCs globally, it has been revealed, that talking about the financial situation - it is rarely a goal to make a profit with IBC initiative. It is considered to be successful if one meets the balance of costs. However, the number undergoing for this venture is growing globally. So how can this be explained?

In another research executed by the authors of this paper, the experts and heads of IBCs internationally were asked, what are the reasons relevant for the founding university when establishing an IBC. The results illustrate the high importance of brand development rather than financial gains. This gives us strong ground to believe that TCA approach is not the leading framework in IBC establishment.

\subsection{Network theory and the industrial network approach}

Networking phenomenon has been widely discussed in the scientific literature in the context of international business for the past two decades (Håkansson \& Johanson, 2002; Johanson \& Mattsson, 2015; Turnbull \& Ellwood, 1986; Turnbull, 1987; Cunningham, 1986; Håkansson \& Ford, 2002; Johanson \& Vahlne, 2009). International orientation while expanding the scope of activities and diversifying the partnerships is a premise of business competitiveness. The more complex are the activities the more complex partner input is necessary and this is the situation where bilateral cooperation is transformed into multilateral partnerships based on networking.

No less significantly is networking emerging in higher education practices. The theory of the latter phenomenon, however, is slightly behind the practice: research of the field analyses occurrences rather than prospect or ties with other theories. Thus, the ties of networking with the Uppsala approach is analysed in this paper.

As discussed above in this paper, originally the Uppsala approach distinguishes two major factors when entering foreign markets: gradually moving from markets with lower psychic distance to markets with higher distance, and incremental step by step approach to intensifying the exporting activities. The Uppsala internationalisation approach was published originally in 1977 by Johanson and Vahlne and have received a considerable amount of criticism since.

Therefore, the extended Uppsala model was presented in 2009. The main factors in the revisited model were trustbuilding and knowledge creation in local networks. As put by Johanson and Vahlne (2009), the most important challenge in the internationalisation is not the psychic distance between the home market and the foreign market, but rather the difficulty to become an insider in local networks. So, networking was considered a very important factor in the process of foreign market entry.

While the original Uppsala model was based on the assumption that market knowledge is gathered through the experience, the new version adds that the market knowledge is acquired through the exchanges within a network: knowledge is gathered not only about own partners, but also about more distant actors in the network. Johanson and Vahlne emphasize trust and commitment building in the network as an important ingredient for successful learning and for the development of new knowledge (Arenius, 2005; Johanson \& Vahlne, 2009; Girdzijauskaite, Radzeviciene, \& Jakubavicius, 2018).

The latter extension relates to the industrial network approach that also addresses the impact of networks in the process of foreign market entry (Turnbull \& Ellwood, 1986; Turnbull, 1987; Cunningham, 1986; Håkansson \& Johanson, 2002; Johanson \& Vahlne, 2009; De Villa et al., 2015; Girdzijauskaite et al., 2018). 


\subsection{Resource-based view and its application in higher education management}

The concept of resource-based view (RBV) was elaborated by J. Barney in 1991. Barney has introduced the basic principles of RBV, also presented the definition of resources, and listed the factors that make a resource a potential source for sustained competitive advantage. There have been other authors interpreting or trying to add to Barney's ideas, nevertheless, the concept didn't change much from that time.

Main theoretical assumptions in resource-based theory are:

- Resources are heterogeneously distributed among organisations;

- Such distribution is steady over time and long lasting;

- Strategic resources are linked to sustained competitive advantage;

- Competitive advantage is sustained only if resources are valuable, rare, imitable, and non-substitutable.

- Basic principles in RBV are complementarity and compatibility;

E. Beerkens in his study (2004) defines the collaboration paradox in the global environment. The essence of his defined paradox is that inter-organizational collaboration (networking) is based on two principles: compatibility and complementarity. The study states that cooperation in a network is successful if the partners are selected similar yet different. Being similar partners satisfy the principle of compatibility while being different the complementarity principle is being satisfied.

However, the resource-based approach is very rarely used in researching higher education management. This phenomenon is partly explained by the fact that the set of strategic resources in the modern university is difficult to determine. It is obvious that such resources as the quality of studies and research have a great value to universities, but very difficult to be identified, classified and evaluated (Altbach \& Knight, 2007).

In order to analyse the scope of business internationalization theories application to higher education management, a review of 5 business internationalization approaches has been made. Sources discussing these approaches in the context of business and higher education have been distinguished accordingly (see Table 1).

Table 1. Comparison between research approaches and theories of the market entry modes (source: compiled by authors)

\begin{tabular}{|c|c|c|c|c|c|}
\hline Approach & Theory & $\begin{array}{l}\text { Major } \\
\text { themes }\end{array}$ & Key factors & Sources in Business & Sources in HE \\
\hline $\begin{array}{l}\text { Uppsala } \\
\text { model }\end{array}$ & $\begin{array}{l}\text { Resource- } \\
\text { based view } \\
\text { theory } \\
\text { Network } \\
\text { theory }\end{array}$ & $\begin{array}{l}\text { Incremental } \\
\text { approach to } \\
\text { resource } \\
\text { commitment } \\
\text { and risk }\end{array}$ & $\begin{array}{l}\text { Experiential } \\
\text { knowledge and net- } \\
\text { works } \\
\text { Trust }\end{array}$ & $\begin{array}{l}\text { (Buckley et al., 1978; Johanson \& } \\
\text { Vahlne, 1977, 2009, 2017) }\end{array}$ & $\begin{array}{l}\text { (Healey, 2008; } \\
\text { Girdzijauskaite \& } \\
\text { Radzeviciene, } \\
\text { 2014; R. Edwards } \\
\text { \& J. Edwards, } \\
\text { 2001) }\end{array}$ \\
\hline $\begin{array}{l}\text { Eclectic } \\
\text { paradigm }\end{array}$ & $\begin{array}{l}\text { Interna- } \\
\text { tional trade } \\
\text { theory } \\
\text { Resource- } \\
\text { based view } \\
\text { theory } \\
\text { Transaction } \\
\text { cost theory }\end{array}$ & $\begin{array}{l}\text { Multi theo- } \\
\text { retical ap- } \\
\text { proach }\end{array}$ & $\begin{array}{l}\text { Cost, size, experien- } \\
\text { tial knowledge, organ- } \\
\text { izational capabili- } \\
\text { ties/FSAs, know-how, } \\
\text { risk, culture, competi- } \\
\text { tion, market charac- } \\
\text { teristics } \\
\text { Networks }\end{array}$ & $\begin{array}{l}\text { (Dunning, 1980, 1988, 1997, } \\
\text { 2015a, 2015b; Root, 1994; } \\
\text { Twomey, 2000) }\end{array}$ & $\begin{array}{l}\text { (Girdzijauskaite } \\
\text { \& Radzeviciene, } \\
\text { 2014; Healey, } \\
\text { 2008; Shams \& } \\
\text { Huisman, 2012) }\end{array}$ \\
\hline $\begin{array}{l}\text { Transac- } \\
\text { tion cost } \\
\text { analysis }\end{array}$ & $\begin{array}{l}\text { Transaction } \\
\text { cost theory }\end{array}$ & $\begin{array}{l}\text { Follows a } \\
\text { cost effi- } \\
\text { cient ra- } \\
\text { tionale }\end{array}$ & Cost & $\begin{array}{l}\text { (Anderson \& Coughlan, 1987; An- } \\
\text { derson \& Gatignon, 1986; Cheung, } \\
\text { 2016; Eriksson, Johanson, Maj- } \\
\text { kgård, \& Sharma, 2015; Klein, } \\
\text { 1989; Laufs \& Schwens, 2014; } \\
\text { Brouthers \& Hennart, 2007) }\end{array}$ & NIA \\
\hline $\begin{array}{l}\text { Industrial } \\
\text { network } \\
\text { approach }\end{array}$ & $\begin{array}{l}\text { Network } \\
\text { theory }\end{array}$ & $\begin{array}{l}\text { Argues in- } \\
\text { dustrial net- } \\
\text { works influ- } \\
\text { ence market } \\
\text { entry modes }\end{array}$ & Networks & $\begin{array}{l}\text { (Axelsson \& Easton, 2016; Cun- } \\
\text { ningham, 1986; Håkansson, 2015; } \\
\text { Håkansson \& Ford, 2002; } \\
\text { Håkansson \& Johanson, 2002; Jo- } \\
\text { hanson \& Mattsson, 2015; Johan- } \\
\text { son \& Vahlne, 2009; Turnbull, } \\
\text { 1987; Turnbull \& Ellwood, 1986) }\end{array}$ & $\begin{array}{l}\text { (Beerkens, 2004; } \\
\text { Girdzijauskaite \& } \\
\text { Radzeviciene, } \\
\text { 2013, 2014; } \\
\text { Radzeviciene \& } \\
\text { Girdzijauskaite, } \\
\text { 2012) }\end{array}$ \\
\hline $\begin{array}{l}\text { Resource- } \\
\text { based } \\
\text { view }\end{array}$ & $\begin{array}{l}\text { Resource- } \\
\text { based theory }\end{array}$ & $\begin{array}{l}\text { Firms gain } \\
\text { competitive } \\
\text { advantage } \\
\text { from re- } \\
\text { sources }\end{array}$ & Resources capabilities & $\begin{array}{l}\text { (Alexy, West, Klapper, \& Reitzig, } \\
\text { 2018; Barney, 1991; Barney, } \\
\text { Ketchen, \& Wright, 2011; Barney, } \\
\text { Wright, \& Ketchen, 2001; Hitt, } \\
\text { Carnes, \& Xu, 2016; Wernerfelt, } \\
\text { 1984) }\end{array}$ & $\begin{array}{l}\text { (Beerkens, 2004; } \\
\text { Radzeviciene \& } \\
\text { Girdzijauskaite, } \\
\text { 2012) }\end{array}$ \\
\hline
\end{tabular}


It is evident from Table 1. 4 that classic internationalisation approaches are much more analysed in a business context than in higher education and there is a need for contribution to the theoretical knowledge in HEIs internationalisation in order to fill the discovered gaps.

Some approaches are interconnected through being based on the same theories or referring to the same key factors. For instance, network theory is the core of industrial network approach and also a very important part of the Uppsala model (especially the new revised version of it (Johanson \& Vahlne, 2009; Vahlne \& Johanson, 2017). Also, the resource-based theory is part of the Uppsala model, eclectic paradigm and of course the resource-based view.

\section{International branch campus as a foreign market entry mode in higher education}

International branch campus may be defined as 'an educational facility owned, at least in part, by a foreign institution, which operates under the name of the foreign institution, where students receive face-to-face instruction to achieve a qualification bearing the name of the foreign institution' (Wilkins \& Huisman, 2012, p. 628). The latter definition is used in this paper.

The international branch campus is not a mainstream foreign MEM tool for higher education institutions - so far just around $1 \%$ of HEIs worldwide undergo such venture. It also may account for only a small proportion of the overall transnational education activities, but it is well known for being the riskiest foreign market entry mode in higher education in terms of finances and reputation (Healey, 2015). A well-known example is the University of New South Wales that withdrew from Singapore within two months of opening in 2007, losing around US\$38 million (Becker, 2009; Wilkins, 2016).

A number of scholars argue that top managers often underestimate the risks of branch campus initiative (Shams \& Huisman, 2012; Wilkins \& Huisman, 2012; Girdzijauskaite \& Radzeviciene, 2014). The main sources of risk in the international branch campus development are a financial risk (high costs), staff (combination and adaptation), product adaptation (curricula), possible reputational damage (Girdzijauskaite \& Radzeviciene, 2014). In fact, staffing an international branch campus with well-qualified staff is one of the biggest challenges facing higher education institutions establishing branches abroad (Shams \& Huisman, 2012, 2014; Girdzijauskaite \& Radzeviciene, 2014).

"Internationalisation affects every part of an HEI and some aspects of it bring potential financial and reputational risk." (Fielden, 2011, p. 4) Some international activities are subject to both locally generated risks (at the level of HEI) and, at the same time, risks that are externally generated (in other countries). The international branch campus is a typical example of such activities (Polak, 2018).

Girdzijauskaite and Radzeviciene (2014) discuss that risks and opportunities should be distinguished into the following categories when establishing a branch campus: environmental factors (government policy, legislation, cultural distance, political risks, higher education zones, macroeconomic risks, etc.), industry factors (student demand, level of competition, etc.) and organisational factors (valuable resources, experiential learning, subject strengths, institutional prestige, financial strength, etc.).

The theories discussed previously and the overview of the predominant risks of IBC establishment form a precondition to the decision support model presented below.

\section{Discussion of results}

Decision support model for the establishment of IBCs is suggested in this paper. Three-stage model is demonstrated in Figure 1.

The main principles of the above model implementation are the following:

- The incremental approach. The sequence of the phases is recommended; however, some steps are likely to be excluded by internationally experienced institutions;

- The interrelatedness of the phases. In every phase preconditions for the further process are made;

- Business approach. The model suggests business-like organisational behaviour for HEIs entering foreign markets as it was proved to be increasingly and successfully applied by mature and experienced HEIs.

The decision support model for the establishment of IBCs consists of three horizontal blocks: the first block deals with the country choice, the second one - with the product identification, and the third one discusses the market entry mode strategy. Also, two vertical sections divide the processes into the internal and external environment of the institution.

After systematizing all the discovered regularities and patterns the decision support model proposed in Figure 1 helps with understanding the processes of IBC development and assists in empowering the higher education institutions in the strategic mapping of the IBC development.

Starting with the first country choice block, as for the internal environment analysis, there is a need for taking into account the HEI partner countries. Previously created and successfully maintained relationships with partners in certain countries provide valuable knowledge of a foreign market and future prospects of market testing and immersion through networking. Knowledge gathered through previous partnerships allows examining the demands in the markets and the coherence of those demands with the services (products) which shall be identified in the next step. 


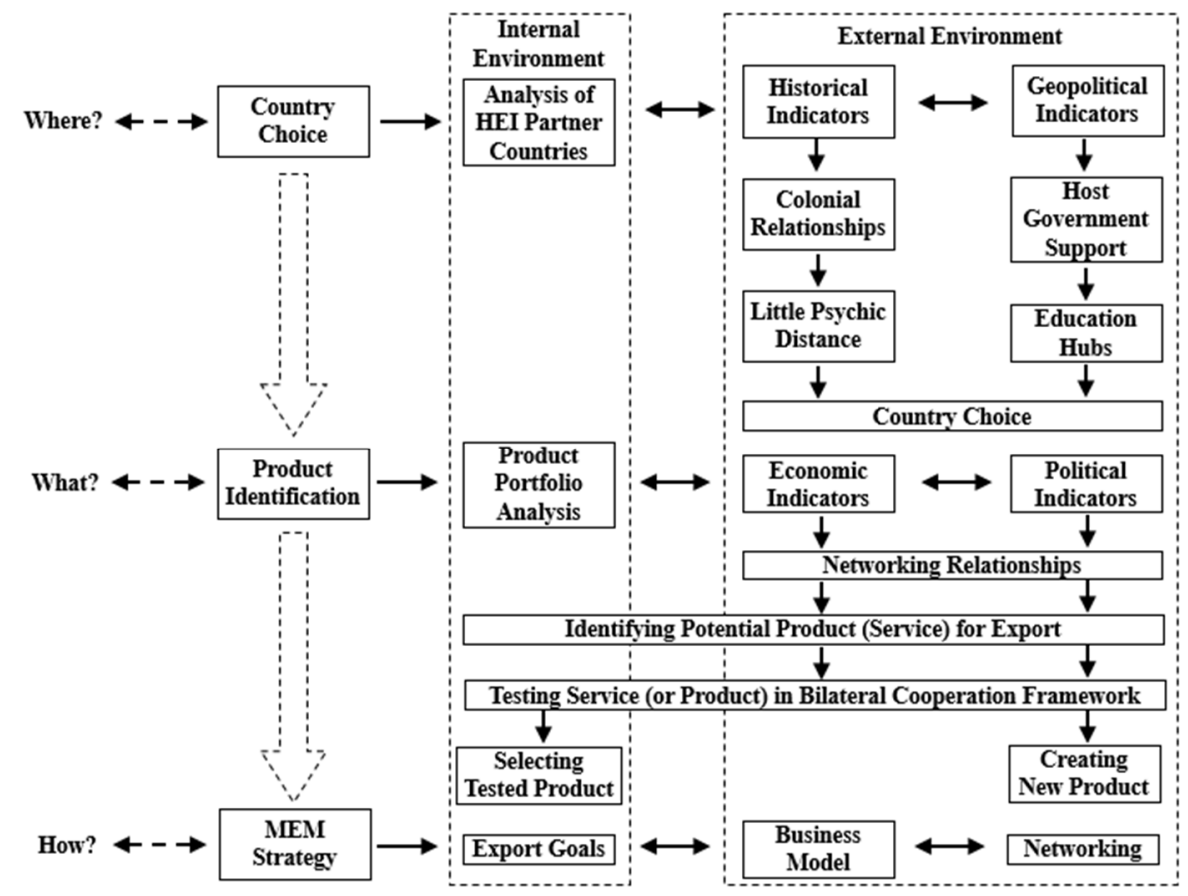

Figure 1. Three-stage model of international branch campus as a foreign market entry mode (source: compiled by authors)

As for the external environment analysis, two groups of indicators are recognized: historical and geopolitical. Historical indicators might be colonial relationships, little psychic distance. Geopolitical indicators play a very important part of choosing a country and areas categorized as follows: host government support, education hubs.

As the expert survey revealed, the political environment of a host country is very important when establishing an international branch campus in a foreign market, therefore it should be well considered. Favourable political environment and local government support might serve as a risk reduction measure, especially in the cases where the government of a receiving country provides foreign HEIs with certain protectionism. And vice versa, the negative political environment might be the determining factor to retreat from the market.

After having taken into consideration these indicators, an institution gets a long list of countries for the possible IBC establishment.

The second block of the decision support model deals with product identification. As for the internal environment part, an institution must perform a current product portfolio analysis in order to identify possible products for the export via IBC. In order to identify the service or product (e.g. programme to be franchised), institutional self-analysis of the product portfolio must be made.

As for the external environment evaluation, economic and political indicators must be evaluated when identifying the product for export. In this part, economic relationships between the countries selected in previous rounds are analysed and the sector demand coherence to the products potentially available for the export.

After the potential products (study programmes, joint or double degree programmes, online courses, non-degree courses, etc.) are identified for the export, it is recommended to test them in a bilateral cooperation framework. Bilateral cooperation includes closer interaction between partners and more direct feedback on the quality of the product.

The third block deals with market entry mode strategy development. Talking about the internal environment, the main aims of this phase are generating and assigning resource base and forming the international branch campus policy. The resource and IBC policy-related measures are financed resource base management and human resource base management, staff recruitment strategy formation, staffing and remuneration policy, developing the tuition policy and product adaptation.

The establishment of an international branch campus requires a strong financial resource base. A branch campus is a rather resource consuming initiative requiring substantial initial investment which in a successful scenario buys off in 2-3 years. In most cases, the IBC establishment is financed by the university itself. In some cases, some support might be received from the host country government (e.g. to support educational services which are oriented to solving the country-specific problems, etc.).

Human resources is an extremely important institutional factor in higher education institutions. Evidently, from the international branch campus research, it is possible to start running an IBC with 4-10 permanent academic staff and 20-50 students. However, the IBC establishment and pre-establishment phase are likely to lead to additional workload and/or unusual tasks for faculty and administration. It is important, therefore, to develop the recruitment strategy of local staff members as well as proper remuneration policy introducing new forms and rules of work organization. 
Moreover, it is recommended that motivation would play an equal role in faculty and administration preparation process: professional placements, work task diversification, to mention a few means (Girdzijauskaite et al., 2018)

During the primary phase of IBC establishment, the institution is very likely to face a shortage of human resources, because of unusual and rare in the market activity. In order to meet the shortage, it is recommended to consider hiring local professionals. A balance between local staff and staff from the main campus of the university has been mentioned in IBC expert surveys multiple times as a very important factor for the adaptation of IBC into the local market (Girdzijauskaite et al., 2018)

Lastly, tuition policy and curricula adaptation are to be considered. These two factors were evaluated as not raising major issues of adaptation by international branch campus experts. Tuition policy - mainly because it is a flexible factor and is easily adjustable in case of IBC. Curricula - because original curricula, foreign teachers and teaching methods are the main value for the customers, seeking authentic experience in an IBC of a foreign university.

The aim of the third block from the perspective of an external environment is determining a risk reduction strategy. As Phillips with co-authors (Phillips et al., 2009) suggests, two important factors in determining the strategy are the institutional difference and institutional uncertainty in a host country. See Figure 2 for the matrix of risk reduction strategies.

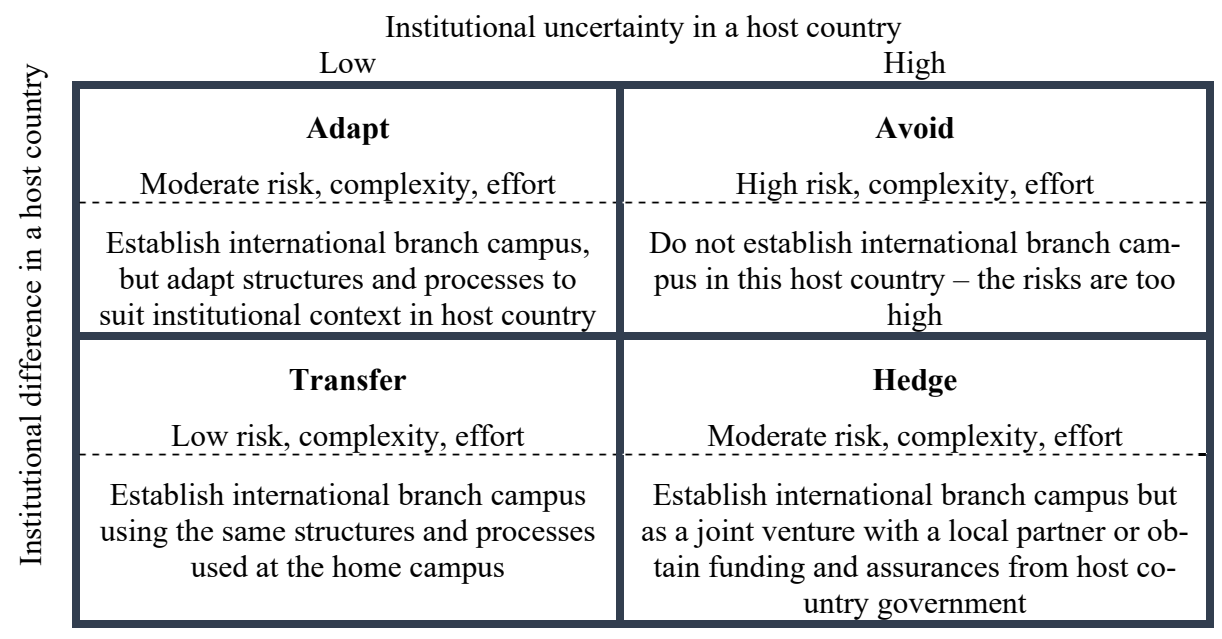

Figure 2. Transnational strategies for a university based on institutional difference and institutional uncertainty (compiled by authors)

In case the institutional difference between the two institutions is low, and the institutional uncertainty in the host country is low, it means a university can transfer the operations to an international branch campus without major changes; similar processes can be used and the same study programmes can be provided with very little or no adaptation at all. This mode, for instance, could be applicable for American HEIs having or about to have branch campuses in Western Europe, Australia or New Zeeland since the uncertainty level for American universities in these markets is rather low.

If institutional differences are high, but the uncertainty in a host country - rather low, then the branch campus can still be established, however, it is going to need more complex revision and adaptation of the processes.

The situation of low institutional differences, but respectively high uncertainty is likely in developing countries (e.g. institutions in a host country are in different marketing stage, have different study model and organisation structure). In such setting risk reduction is possible through a local partnership (with HEIs, non-university educational institutions, business companies, etc.) - then, a university is able to convey an image of legitimacy, and when the strategy is seen to be successful, it is likely to be imitated by other universities. An example of a respective strategy is well applied in branch campuses established in Malaysia between 1996 and 2007 between foreign universities and local colleges, where the colleges provided foreign HEIs with market intelligence, capital and physical infrastructure, while HEIs took the lead in educational components. (Girdzijauskaite et al., 2018)

Both the institutional differences and uncertainty between home and host countries result in vast risks and the effort required might not be worth the possible benefits. In India, for instance, there is a huge undersupply of higher education, yet the complex regulatory frame decreases the country attractiveness to foreign universities seeking overseas expansion.

Analysis of the risk reduction strategies shows that when the uncertainty is high, a joint venture with a local institution is recommended. For the universities that entered the education market later than their rivals, a joint venture might be considered as less risky entry mode for HEI. 


\section{Conclusions}

It is widely discussed in the literature that the internationalisation of higher education follows similar paths as multinational corporations. In total five business internationalisation approaches and their applicability to higher education management were analysed in the paper: Uppsala internationalisation theory, eclectic paradigm, transaction cost theory, industrial network approach and the resource-based view. Finally, Uppsala approach and the networking theory were chosen as a framework for the final model development.

The incremental nature of internationalisation and the business approach has been incorporated into the comprehensive decision support model for international branch campus establishment enhancing the university competitiveness. From a practical point of view, higher education institutions could employ this tool and develop better internationalisation strategies that could lead to better allocation of resources and improve the competitiveness of an HEI.

The model is significant for the HEIs due to the following reasons:

- The obtained results and the decision support model will contribute to the existing internationalisation practices of HEIs considering entering new foreign markets in the form of international branch campus.

- The model is universal and could be used for management purposes in all higher education institutions from advanced large universities to small colleges and schools. It is especially helpful for the latecomer HEIs that consider IBCs as too risky and radical.

- The decision support model is an instructional map for the top management in HEIs, contributing to the strategic and systematic approach to the international branch campus establishment.

Theoretical and empirical research executed by the authors and covered in this and previous research papers (Girdzijauskaite \& Radzeviciene, 2014; Girdzijauskaite et al., 2018; Radzeviciene \& Girdzijauskaite, 2012) confirms practical applicability of the decision support model for international branch campus establishment enhancing the university competitiveness and reveals the perspectives and limitations for its use.

The following limitations of the decision support model have been distinguished: (1) the model is constructed for the establishment phase of international branch campus; (2) the indicators of the political environment, population growth, natural conditions and disasters are neglected.

\section{Disclosure statement}

Authors do not have any competing financial, professional, or personal interests from other parties.

\section{References}

Alexy, O., West, J., Klapper, H., \& Reitzig, M. (2018). Surrendering control to gain advantage: Reconciling openness and the resource-based view of the firm. Strategic Management Journal, 39(6), 1704-1727. https://doi.org/10.1002/smj.2706

Altbach, P. G., \& Knight, J. (2007). The Internationalisation of higher education: motivations and realities. Journal of Studies in International Education, 11(3-4), 290-305. https://doi.org/10.1177/1028315307303542

Anderson, E., \& Coughlan, A. T. (1987). International market entry and expansion via independent or integrated channels of distribution. The Journal of Marketing, 71-82. https://doi.org/10.1177/002224298705100106

Anderson, E., \& Gatignon, H. (1986). Modes of foreign entry: A transaction cost analysis and propositions. Journal of International Business Studies, 17(1986), 1-26. https://doi.org/10.1057/palgrave.jibs.8490432

Andersson, U., Johanson, J., \& Vahlne, J. E. (1997). Organic acquisitions in the internationalization process of the business firm. MIR: Management International Review, 67-84.

Arenius, P. (2005). The psychic distance postulate revised: from market selection to speed of market penetration. Journal of International Entrepreneurship, 3(2), 115-131. https://doi.org/10.1007/s10843-005-4203-6

Axelsson, B., \& Easton, G. (2016). Industrial Networks (Routledge Revivals): A new view of reality. Routledge. https://doi.org/10.4324/9781315629629

Barney, J. B. (1991). Firm resources and sustained competitive advantage. Journal of Management, 17(1), 99-120. https://doi.org/10.1177/014920639101700108

Barney, J. B., Ketchen, Jr, D. J., \& Wright, M. (2011). The future of resource-based theory: revitalization or decline? Journal of Management, 37(5), 1299-1315. https://doi.org/10.1177/0149206310391805

Barney, J. B., Wright, M., \& Ketchen, D. J. (2001). The resource-based view of the firm: Ten years after 1991. Journal of Management, 27, 625. https://doi.org/10.1177/014920630102700601

Becker, R. F. (2009). International branch campuses: Markets and strategies. Observatory on Borderless Higher Education.

Beerkens, E. (2004). Global opportunities and institutional embeddedness: higher education consortia in Europe and Southeast Asia. Center for Higher Education Policy Studies (CHEPS).

Brouthers, K. D., \& Hennart, J. F. (2007). Boundaries of the firm: Insights from international entry mode research. Journal of management, 33(3), 395-425. https://doi.org/10.1177/0149206307300817

Buckley, P. J., Newbould, G. D., \& Thurwell, J. C. (1978). Going international: The foreign direct investment behaviour of smaller UK firms. University of Reading, Department of Economics. 
Cheung, S. N. (2016). Economic organization and transaction costs. The new palgrave dictionary of economics, 1-5. https://doi.org/10.1057/978-1-349-95121-5_375-1

Cunningham, M. T. (1986). The British approach to Europe. Strategies for international industrial marketing, 165-203.

De Villa, M. A., Rajwani, T., \& Lawton, T. (2015). Market entry modes in a multipolar world: Untangling the moderating effect of the political environment. International Business Review, 24(3), 419-429. https://doi.org/10.1016/j.ibusrev.2014.10.001

Dunning, J. H. (1988). The theory of international production. The International Trade Journal, 3(1), 21-66. https://doi.org/10.1080/08853908808523656

Dunning, J. H. (1997). Re-evaluating the benefits of foreign direct investment. In J. H. Dunning (Ed.), Alliance capitalism and global business. Routledge, London. https://doi.org/10.4324/9780203016527.pt3

Dunning, J. H. (2015a). The eclectic paradigm of international production: a restatement and some possible extensions. In The Eclectic Paradigm (pp. 50-84). London: Palgrave Macmillan. https://doi.org/10.1007/978-1-137-54471-1_3

Dunning, J. H. (2015b). Reappraising the eclectic paradigm in an age of alliance capitalism. In The eclectic paradigm (pp. 111142). London: Palgrave Macmillan. https://doi.org/10.1007/978-1-137-54471-1_5

Dunning, John H. (1980). Toward an eclectic theory of international production: some empirical tests. Journal of International Business Studies, Spring/Summer, 9-31. https://doi.org/10.1057/palgrave.jibs.8490593

Edwards, R., \& Edwards, J. (2001). Internationalisation of education: A business perspective. Australian Journal of Education, 45(1), 76-89. https://doi.org/10.1177/000494410104500107

Ennew, C. T. (2012). Around the world in 80 ways: routes to internationalization in higher education. In The Globalization of Higher Education (pp. 70-90). London: Palgrave Macmillan. https://doi.org/10.1057/9781137265050_6

Eriksson, K., Johanson, J., Majkgård, A., \& Sharma, D. D. (2015). Experiential knowledge and cost in the internationalization process. In Knowledge, Networks and Power (pp. 41-63). London: Palgrave Macmillan. https://doi.org/10.1057/9781137508829_2

Fielden, J. (2011). Getting to grips with internationalisation. Resources for UK higher education institutions. London: Leadership Foundation, for HE and the Committee of University Chairs.

Girdzijauskaite, E., \& Radzeviciene, A. (2013). Opportunities of competitiveness of latecomer university. Proceedings of the 16th Conference for Junior Researchers "Science - Future of Lithuania" (pp. 24-28), Vilnius: Technika. ISSN 2029-7149.

Girdzijauskaite, E., \& Radzeviciene, A. (2014). International branch campus: Framework and strategy. Procedia-Social and Behavioral Sciences, 110, 301-308. https://doi.org/10.1016/j.sbspro.2013.12.874

Girdzijauskaite, E., Radzeviciene, A., \& Jakubavicius, A. (2018b). International branch campus: sequential market commitment. Journal of System and Management Sciences, 8(4), 57-81. ISSN 1816-6075 (Print), 1818-0523 (Online).

Håkansson, H. (2015). Industrial technological development (Routledge Revivals): A Network approach. Routledge. https://doi.org/10.4324/9781315724935

Håkansson, H., \& Ford, D. (2002). How should companies interact in business networks. Journal of Business Research, 55(2), 133139. https://doi.org/10.1016/S0148-2963(00)00148-X

Håkansson, H., \& Johanson, J. (2002). A model of industrial networks. Understanding Business Marketing and Purchasing: An Interaction Approach, 145.

Healey, N. M. (2008). Is higher education in really "internationalising"? Higher education, 55(3), 333-355. https://doi.org/10.1016/S0148-2963(00)00148-X

Healey, N. M. (2015). Towards a risk-based typology for transnational education. Higher Education, 69(1), 1-18. https://doi.org/10.1007/s10734-014-9757-6

Hitt, M. A., Carnes, C. M., \& Xu, K. (2016). A current view of resource-based theory in operations management: A response to Bromiley and Rau. Journal of Operations Management, 41(10), 107-109. https://doi.org/10.1016/j.jom.2015.11.004

Johanson, J., \& Mattsson, L. G. (2015). Internationalisation in industrial systems - a network approach. In Knowledge, networks and power (pp. 111-132). London: Palgrave Macmillan. https://doi.org/10.1057/9781137508829_5

Johanson, J., \& Vahlne, J. E. (1977). The internationalization process of the firm - a model of knowledge development and increasing foreign market commitments. Journal of International Business Studies, Spring/Summer, 23-32. https://doi.org/10.1057/palgrave.jibs.8490676

Johanson, J., \& Vahlne, J. E. (2009). The Uppsala internationalization process model revisited: From liability of foreignness to liability of outsidership. Journal of International Business Studies, 40(9), 1411-1431. https://doi.org/10.1057/jibs.2009.24

Kim, E. H., \& Zhu, M. (2010). Universities as firms: The case of US overseas programs. In American universities in a global market (pp. 163-201). University of Chicago Press. https://doi.org/10.7208/chicago/9780226110455.003.0006

Klein, S. (1989). A transaction cost explanation of vertical control in international markets. Journal of the Academy of Marketing Science, 17(3), 253-60. https://doi.org/10.1007/BF02729817

Laufs, K., \& Schwens, C. (2014). Foreign market entry mode choice of small and medium-sized enterprises: A systematic review and future research agenda. International Business Review, 23(6), 1109-1126. https://doi.org/10.1016/j.ibusrev.2014.03.006

Naidoo, V. (2009). Transnational higher education: A stock take of current activity. Journal of Studies in International Education, 13(3). https://doi.org/10.1177/1028315308317938

Phillips, N., Tracey, P., \& Karra, N. (2009). Rethinking institutional distance: strengthening the tie between new institutional theory and international management. Strategic Organization, 7, 339-348. https://doi.org/10.1177/1476127009337439

Polak, M. (2018). Risk management in internationalisation of higher education - a practical institutional approach. Internationalisation of Higher Education, 2, 23-49. 
Radzeviciene, A., \& Girdzijauskaite, E. (2012). Multilateral partnership management in higher education: the network approach. Contemporary issues in business, management and education. Conference proceedings. Vilnius.

Root, F. R. (1994). Entry strategies for international markets. New York: Lexington Books.

Shams, F., \& Huisman, J. (2012). Managing offshore branch campuses: An analytical framework for institutional strategies. Journal of Studies in International Education, 16(2), 106-127. https://doi.org/10.1177/1028315311413470

Shams, F., \& Huisman, J. (2014). The role of institutional dual embeddedness in the strategic local adaptation of international branch campuses: Evidence from Malaysia and Singapore. Studies in Higher Education, 1-16. https://doi.org/10.1080/03075079.2014.966669

Turnbull, P. W. (1987). A challenge to the stages theory of the internationalization process. Managing export entry and expansion, 21-40.

Turnbull, P. W., \& Ellwood, S. (1986). Internationalisation in the information technology industry. UMIST.

Twomey, M. J. (2000). A century of foreign investment in the third world (Book). Routledge (p. 8). ISBN 0-415-23360-7.

Vahlne, J. E., \& Johanson, J. (2017). From internationalization to evolution: The Uppsala model at 40 years. Journal of International Business Studies, 48(9), 1087-1102. https://doi.org/10.1057/s41267-017-0107-7

Wernerfelt, B. (1984). A resource-based view of the firm. Strategic Management Journal, 5(2), 171-180. https://doi.org/10.1002/smj.4250050207

Wilkins, S. (2016). Establishing international branch campuses: a framework for assessing opportunities and risks. Journal of Higher Education Policy and Management, 38(2), 167-182. https://doi.org/10.1080/1360080X.2016.1150547

Wilkins, S., \& Huisman, J. (2012). The international branch campus as transnational strategy in higher education. Higher Education, 64(5), 627-645. https://doi.org/10.1007/s10734-012-9516-5 